\title{
ANALISIS FAKTOR TITIK KRITIS DAN UJI MALACHITE GREEN UNTUK MENENTUKAN STATUS HALAL AYAM POTONG DI TPA KECAMATAN MENES
}

\author{
Marlinda Indriati $^{1^{*}}$, Tuti Rostianti Maulani ${ }^{2}$, Uti Nurliawati ${ }^{3}$ \\ ${ }^{1,2.3}$ Universitas Mathla'ul Anwar, J1 Raya Labuan Km 23 Cikaliung \\ Saketi Kabupaten Pandeglang Banten, Indonesia \\ Korespondensi Author: e-mail: marlinda.indriati87@gmail.com
}

\begin{abstract}
This study aims to analyze the critical point factor and malachite green test to determine the halal status of broiler chickens in chicken slaughterhouses (TPA). Samples were taken from 4 landfills in Menes District. The research was conducted in 3 stages, namely first filling the halal slaughtering quisoner according to the LPPOM MUI standard (2011), with results of $80 \%$ in accordance with the halal chicken slaughtering technique. The second stage is the Malachite Green test, which aims to prove whether the process of slaughtering broiler chickens is perfect, seen from the removal of chicken blood which must also be perfect, the data obtained is that blood removal is carried out completely from all samples (negative carcass). The last stage is post-slaughter handling by testing Eacherichia coli microbial contamination. The average value of microbial contamination is $2.6 \times 104$ cfu I gr with purple colonies on brilliance media, and the amount of e.coli contamination of broiler chicken meat exceeds the maximum limit of Eacherichia Coli microbial contamination (BMCM) of fresh chicken meat is less than $1 \times 101 \mathrm{cfu} / \mathrm{gr}$.
\end{abstract}

Keywords: Halal; Broiler Chicken; TPA; Malachite Green.

Abstrak: Penelitian ini bertujuan untuk menganalisis faktor titik kritis dan uji malachite green untuk menentukan status halal ayam broiler di tempat pemotongan ayam (TPA). Sampel diambil dari 4 TPA yang berada di Kecamatan Menes. Penelitian dilakukan dengan 3 tahap yaitu pertama pengisian quisoner penyembelihan halal sesuai dengan standar LPPOM MUI (2011), dengan hasil $80 \%$ telah sesuai dengan teknik pemotongan ayam halal. Tahap ke 2 yaitu uji Malachite Green yang bertujuan untuk membuktikan apakah proses penyembelihan ayam broiler sudah sempurna dilihat dari pengeluaran darah ayam yang juga harus sempurna, data yang diperoleh pengeluaran darah dilakukan secara sempurna dari semua sampel (Negatif bangkai). Tahap terakhir yaitu penanganan pasca penyembelihan dengan pengujian cemaran mikroba Eacherichia coli. Nilai cemaran mikroba rata-rata 2,6 x $10^{4} \mathrm{cfu} / \mathrm{gr}$ dengan koloni berwarna ungu pada media brilliance, dan jumlah cemaran e.coli daging ayam broiler melebihi batas maksimum cemaran mikroba (BMCM) Eacherichia Coli daging ayam segar adalah kurang dari 1 x $10^{1} \mathrm{cfu} / \mathrm{gr}$.

Kata Kunci: Halal; Ayam Broiler; TPA; Malachite Green.

\section{PENDAHULUAN}

Daging ayam merupakan bahan pangan asal ternak yang digemari oleh masyarakat karena gizinya tinggi, harganya tergolong murah dan penting untuk memenuhi kebutuhan protein hewani (Delfita rina, 2013). Kehalalan dan keamanan asal ternak harus di 
perhatiakan, mulai dari proses pemotongan hinga dikonsumsi oleh konsumen. Sebagaian masyarakat kurang begitu memahami tentang keamanan pada pangan termasuk pada daging ayam, kondisi ini cukup memprihatinkan, karena daging ayam merupakan salah satu bahan pangan yang mudah rusak dan sangat mudah terkontaminasi bakteri.

Selain keamanan pangan, produk makanan juga harus halal termasuk pada daging ayam boiler yang di konsumsi, sesuai dengan UU No 332014 terkait jaminan produk halal, yang dimana pada pasal 4 di terangkan bahwa produk yang masuk dan beredar di Indonesia harus bersertifikasi halal, oleh karena itu kehalalan pada produk sangat penting termasuk pada daging ayam boiler karena ada beberapa titik kritis seperti pada penyembelihannya.

Kehidupan seorang muslim berkaitan erat dengan konsep halal dan haram. Konsep ini bersifat menyeluruh karena tidak hanya di aplikasikan pada makanan dan minuman, namun juga memperoleh nafkah, tata cara berpakayan dan berkomunikasi dengan mahluk hidup lainnya (Riaz dan Chaudry, 2004).

Metode pengujian yang digunakan dalam deteksi daging bangkai yaitu metode Malachite Green (MG). Penelitian ini merupakan modifikasi dari uji malachite green (MG) yang digunakan untuk pengujian kesempurnaan pengeluaran darah pada pemotongan hewan sapi. Pada dasarnya MG berkompetisi dengan hemoglobin $(\mathrm{Hb})$ untuk mengikat oksigen. Karena $\mathrm{Hb}$ mempunyai afinitas lebih tinggi dari $\mathrm{MG}$, maka $\mathrm{Hb}$ akan mengikat Oksigen lebih dahulu. Pengeluaran darah positif (+) tidak sempurna jika larutan campuran ekstrak daging (3\%) dan MG (2\%) berwarna hijau keruh, sedang hasil negatif (-) sempurna jika larutan berwarna hijau-biru jemih (Anonim, 1996b).

Berdasarkan hal tersebut diatas, maka perlu dilakukan penelitian yang bertujuan untuk menganalisis faktor titik kritis dan uji Malachite Green untuk menentukan status halal ayam potong di tempat pemotongan ayam Kecamatan Menes.

\section{METODE}

\section{Alat dan Bahan}

Alat-alat yang digunakan dalam pengujian kimia diantaranya : Timbangan neraca analitik, labu Erlenmeyer, korek api, pembakar spirtus, pisau, Gunting, larutan alkohol 70\%, tabung reaksi, pipet, plastik steril, stomacher, kabinet,Vortex mixer, Freezer.

Bahan-bahan yang digunakan dalam pengujian Malachite Green diantaranya :Daging ayam boiler, akuades, Malachite Green, danH $\mathrm{H}_{2} \mathrm{O}_{2}$. Bahan-bahan yang digunakan dalam pengujian Ecoli diantaranya :Media BPW (Buffer Pepton Water), Media Brileance, Air aquades,

\section{Prosedur Penelitian}

\section{Survey lokasi}

Lokasi pengambilan sampel di lakukan di 4 TPA kecamatan Menes. Masing-masing TPA diambil 2 sampel sehingga sampel yang di uji yaitu 8 sampel. Untuk control positif bangkai (tidak disembelih) di ambil di salah satu TPA Kecamatan Menes. 


\section{Pengumpulan Sampel}

Metode Sampling daging ayam boiler mengikuti metode Purose Sampling (Sulaiman Rasyid, 2014) yaitu sampel yang diambil berdasarkan kreteria tertentu yang sesuai dengan tujuan penelitian yang dianggap dapat mewakili penelitian. Adapun kreteria yang digunakan untuk memilih sampel penelitian adaah sebagai berikut :

1. Pengumpulan sampel dilakukan terhadap 8 sampel daging ayam boiler dengan TPA yang berada di Kecamatan Menes

2. Sampel dipilih dari produsen TPA menjajakan daging ayam boiler dengan menetap di kios permanen di sekitar pasar Kecamatan Menes

3. Daging ayam boiler telah luas di kenal masyarakat dengan cara membeli secara tunai. Sampel dari TPA didapatkan dalam keadaan mentah.

\section{Rancangan Penelitian}

Penelitian dilakukan secara deskriptif dengan pemeriksaan kualitatif terkadap deteksi Teknik Pemotongan ayam broiler, pengeluaran darah secara sempurna dengan Metode Malachite Green dan cemaran Escherichia Coli yang ada di daging ayam boiler di Tempat Pemotongan Ayam Kecamatan Menes.

\section{Wawancara}

Wawancara yang dilakukan pada penelitian ini yaitu dengan jagal ayam broiler di TPA Kecamatan Menes. Beberapa pertanyaan yang di ajukan kepada narasumber terkait Teknik Pemotongan Ayam yang Halal Mengacu Pada LPPOM MUI (2011).

Prosedur Pengujian Malachite Green (Drastini dan Yudhabuntara, 2000)

Dibuat ekstrak daging $100 \%$ dengan cara menimbang 50 gram daging paha. Kemudian daging dipotong-potong kecil dengan gunting dan haluskan dengan mortar. Setelah halus tambahkan $50 \mathrm{ml}$ akuades, kemudian dimasukkan kedalam tabung Erlenmeyer dan didiamkan 12 menit. Ekstrak daging di ambil 2 ml, kemudian dimasukan kedalam tabung reaksi.

Tambahkan 2 tetes Malachite Green diaduk dengan cara di vortex, tambahkan 2 tetes $\mathrm{H}_{2} \mathrm{O}_{2} 3 \%$ kemudian di vortex kembali. Pembacaan hasil apabila berubah warna menjadi hijau berarti (+) daging bangkai dan apabila berubah warna menjadi biru (-) bukan daging bangkai.

\section{Prosedur Pengujian Escherichia coli Pada Daging Ayam}

Timbang sampel sebanyak 25 gram,tambahkan larutan bpw yang sudah di autoclave sebanyak $225 \mathrm{ml} / \mathrm{sampel}$, mixer dengan menggunakan alat stomacher. Lalu dilakukan pengenceran menggunakan tabung reaksi berisi bpw sebanyak $9 \mathrm{ml}$. Tuangkan sampel ke dalam tabung reaksi sebanyak $1 \mathrm{ml}$.

Dimasukan $1 \mathrm{ml}$ sampel lalu tuangkan media brilience yang sudah direbus ke dalam cawan petri sebanyak $15 \mathrm{ml} / \mathrm{cawan}$ petri.kemudian goyangkan cawan petri sampai tercampur dan merata,di putar seperti membentuk angka 8. masukan ke dalam inkubator dalam suhu $42^{0}$ C,inkubasi selama 24 


\section{HASIL DAN PEMBAHASAN}

Tabel 4.1 Kesesuaian Tata cara Penyembelihan Ayam Halal di TPA tempat penelitian Berdasarkan Prosedur LPPOM MUI (2011)

\begin{tabular}{llc}
\hline No & \multicolumn{1}{c}{ Desa } & $\begin{array}{c}\text { Tata cara } \\
\text { penyembelihan } \\
(\%)\end{array}$ \\
\hline 1. & Menes & 90 \\
2. & Menes & 90 \\
3. & Sukamanah & 90 \\
4. & Muruy & 90 \\
\hline
\end{tabular}

Keterangan bobot penilaian :

$75 \%-100 \%$ = Sesuai

$50 \%-75 \%=$ Kurang sesuai

$25 \%-50 \%=$ Tidak sesuai

$0 \%-25 \%=$ Tidak sesuai sekali

Tabel 2. Hasil Evaluasi Terhadap Kesesuaian Pemotongan Ayam yang Halal Mengacu Pada LPPOM MUI (2011)

\begin{tabular}{|c|c|c|}
\hline No & Proses Pemotongan & TPA \\
\hline 1. & $\begin{array}{l}\text { Petugas Penyembelih di } \\
\text { control dan di suprevisi } \\
\text { LPPOM MUI }\end{array}$ & $0 / 4$ \\
\hline 2. & $\begin{array}{l}\text { Penyembelih beragama } \\
\text { islam, berumur lebih dari } \\
18 \text { tahun dan sehat jiwa } \\
\text { dan jasmani }\end{array}$ & $4 / 4$ \\
\hline 3. & $\begin{array}{l}\text { Penyembelih lulus } \\
\text { pelatihan halal oleh } \\
\text { lembaga islam/lembaga } \\
\text { yang berwenang }\end{array}$ & $0 / 4$ \\
\hline 4. & $\begin{array}{l}\text { Penyembelih memahami } \\
\text { tata cara penyembelihan } \\
\text { sesuai syariat islam }\end{array}$ & $4 / 4$ \\
\hline 5. & $\begin{array}{l}\text { Alat Penyembelih harus } \\
\text { tajam, bukan kuku, dan } \\
\text { bukan taring/tulang }\end{array}$ & $4 / 4$ \\
\hline 6. & $\begin{array}{l}\text { Penyembelih memiliki } \\
\text { kartu identitas dari } \\
\text { lembaga sertifikat halal } \\
\text { oleh MUI/ Lembaga yang } \\
\text { berwenang. }\end{array}$ & $0 / 4$ \\
\hline
\end{tabular}


7. Sebelum di sembelih ayam $4 / 4$ di istirahatkan

8. Pengendalian ayam $4 / 4$ semaksimal mungkin sehingga tidak stress dan kesakitan

9. Penyembelihan di lakukan $4 / 4$ menghadap kiblat dan mengucapkan "Bismilllahirahmanirahim "

10. memotong oesophagus, 4/4 trachea, vena jagularis dan arteri karotis

11. Penyembelihan hanya $4 / 4$ sekali dari leher depan dan tidak memutus tulang leher depan dan tidak memutus tulang leher

12. Alat transportasi tidak di $4 / 4$ gunakan produk non-halal.
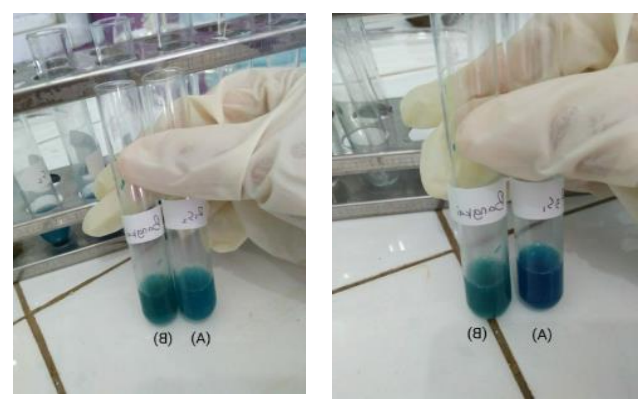

Gambar 1. Uji Malachite Green pada daging ayam broiler

Keterangan : A = Sempel

$\mathrm{B}=$ Control Positif

Tabel 2 Hasil Uji Malachite Green pada daging ayam broiler

\begin{tabular}{lllc}
\hline Kode & Lokasi & $\begin{array}{l}\text { Jenis } \\
\text { sampel }\end{array}$ & MG \\
\hline R1S1 & Menes & $\begin{array}{l}\text { Daging } \\
\text { ayam }\end{array}$ & Negatif \\
R1S2 & Menes & $\begin{array}{l}\text { Daging } \\
\text { ayam }\end{array}$ & Negatif \\
R2S1 & Menes & $\begin{array}{l}\text { Daging } \\
\text { ayam }\end{array}$ & Negatif \\
\hline
\end{tabular}




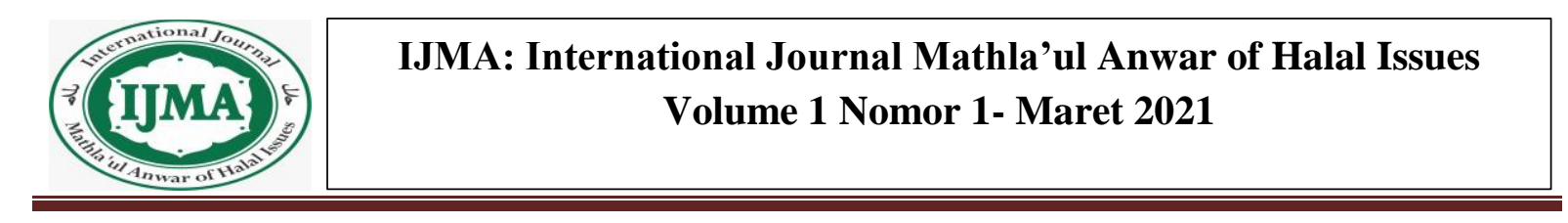

\begin{tabular}{|c|c|c|c|}
\hline R2S2 & Menes & $\begin{array}{l}\text { Daging } \\
\text { ayam }\end{array}$ & Negatif \\
\hline R3S1 & Sukamanah & $\begin{array}{l}\text { Daging } \\
\text { ayam }\end{array}$ & Negatif \\
\hline R3S2 & Sukamanah & $\begin{array}{l}\text { Daging } \\
\text { ayam }\end{array}$ & Negatif \\
\hline R4S 1 & Muruy & $\begin{array}{l}\text { Daging } \\
\text { ayam }\end{array}$ & Negatif \\
\hline $\mathrm{R} 4 \mathrm{~S} 2$ & Muruy & $\begin{array}{l}\text { Daging } \\
\text { ayam }\end{array}$ & Negatif \\
\hline
\end{tabular}

Tabel 4.3.1 Rata-rata jumlah ecoli pada karkas ayam dari TPA Kecamatan

\begin{tabular}{cllc}
\hline No & Sampel & Lokasi & MG \\
\hline 1. & R1S1 & Menes & $1,4 \times 10^{4}$ \\
2. & R1S2 & Menes & $2,3 \times 10^{4}$ \\
3. & R2S1 & Menes & $6,9 \times 10^{4}$ \\
4. & R2S2 & Menes & $4,0 \times 10^{4}$ \\
5. & R3S1 & Sukam & $2,0 \times 10^{4}$ \\
6. & R3S2 & $\begin{array}{l}\text { Sukam } \\
\text { anah }\end{array}$ & $2,7 \times 10^{4}$ \\
7. & R4S1 & Muruy & $1,5 \times 10^{4}$ \\
8. & R4S2 & Muruy & TBUD \\
\hline \multicolumn{7}{l}{ Rata-rata } & & $2,6 \times 10^{4}$
\end{tabular}

Proses pemotongan yang halal tergantung dari sarana, sumber daya manusia, tata cara penyembelihan penyimpanan, pengemasan dan pemisahan dengan kotoran. bersasarkan dari data wawancara terhadap responden tata cara penyembelihan yang halal di TPA kecamatan menes dilihat pada Tabel 1.

Berdasarkan tabel tata cara penyembelihan ayam di TPA Kecamatana Menes dilakukan sesuai dengan LPPOM MUI (2011), dan seluruh TPA melakukan penyembelihan yang tidak berbeda. Sebelum di sembelih ayam-ayam di istirahatkan agar tidak stress pada saat di sembelih dan pada saat pengeluaran darah di keluarkan secara sempurna dapat di lihat pada saat uji Malachite Green . Penyembelih beragama islam dan berumur lebih dari 18 tahun sehat jasmani dan rohani, penyembelih memahami tata cara penyembelihan sesuai syariat islam, alat penyembelih yang digunakan tajam, bukan dari kuku, gigi atau taring tulang, sebelum di sembelih ayam di istirahatkan, pengendalian ayam semaksimal mungkin sehingga tidak stress dan kesakitan, penyembelihan di lakukan menghadap kiblat dan mengucapkan "Bismilllahirahmanirahim", hal ini sesuai dengan Al-quran surat Al an'am ayat 118, yang artinya "Maka makanlah binatang-binatang (yang halal) yang disebut nama Allah” (QS.Al an’am:118). 


\section{IJMA: International Journal Mathla'ul Anwar of Halal Issues \\ Volume 1 Nomor 1- Maret 2021}

Memotong oesophagus, trachea, vena jagularis dan arteri karotis, penyembelihan hanya sekali dari leher depan dan tidak memutus tulang leher depan dan tidak memutus tulag leher, alat transfortasi tidak di gunakan produk non-halal. Pada penelitian ini dilakukan pengamatan terhadap kesesuaian pemotongan ayam untuk mengetahui sejauh mana ayamayam di potong secara halal di TPA Kecamatan Menes. Hasil evaluasi terhadap kesesuaian hasil pemotongan ayam halal di TPA Kecamatan Menes yang mengacu pada LPPOM MUI (2011) tersaji pada tabel 2.

Dari Hasil kuisoner tata cara penyembelihan sudah sesuai dengan kreteria halal, sesuai dengan standar LPPOM MUI dengan bobot nilai $90 \%$, meskipun belum memiliki legalitas dan belum adanya pelatihan penyembelihan ayam secara halal di Tempat Pemotongan Ayam di Kecamatan Menes. Untuk meyakinkan bahwa proses tersebut merupakan proses penyembelihan yang benar, dilakukan uji Malachite Green sebagai salah satu untuk mengetahui apakah darah yang keluar pada saat penyembelihan ayam telah keluar secara sempurna atau tidak. Menurut Marwan (2012) penyembelihan itu harus dilakukan dileher binatang tersebut yaitu : bahwa kematian binatang tersebut justru sebagai akibat dari terputusnya urat nadi atau kerongkonnya. Penyembelihan yang paling sempurna, yaitu terputusnya kerongkongan, tenggorokan, dan urat nadi. Ayam diyakini sudah mati sebelum diproses lebih lanjut.

Hasil dari pengujian Malachite Green terlihat pada Gambar 1, terlihat pada sampel semua TPA mengalami perubahan warna menjadi biru dan pada control positif berubah mejadi hijau . Warna biru menandakan hasil negatif (bukan ayam bangkai) dan warna hijau (ayam bangkai) menandakan hasil positif bangkai, hal ini menunjukan pada sampel dari semua TPA negatif bangkai atau pengeluaran darah dilakukan secara sempurna. Menurut Marwan (2012) penyembelihan itu harus dilakukan dileher binatang tersebut yaitu : bahwa kematian binatang tersebut justru sebagai akibat dari terputusnya urat nadi atau kerongkonnya.

Hasil dari pengujian Malachite Green terlihat Pada Gambar 1, terlihat pada sampel semua TPA mengalami perubahan warna menjadi biru dan pada control positif berubah mejadi hijau. Warna biru menandakan hasil negatif (bukan ayam bangkai) dan warna hijau (ayam bangkai) menandakan hasil positif.

Berdasarkan tabel di atas uji Malachite Green teknik pemotongan ayam di TPA kecamatan Menes, pemotongan ayam di lakukan secara sempurna, karena pengeluaran darah pada ayam keluar secara sempurna, dibuktikan dengan hasil uji Malachite Green negatif (bukan daging bangkai). Sehingga teknik pemotongan yang dilakukan tidak menyebabkan darah mengendap di dalam karkas atau tidak megalami pembusukan sehingga status daging ayam bukan daging bangkai.

Berdasarkan tabel 4.3 dapat di ketahui bahwa jumlah rata-rata Escherichia Coli pada karkas ayam di TPA Kecamatan Menes yang ada di 4 TPA dengan masing masing sampel 2 karkas ayam yaitu 2,6 × $10^{4}$ melebihi batas maksimum cemaran mikroba menurut SNI 
7388:2009, yaitu $<10^{1} \mathrm{cfu} / \mathrm{g}$. Pencemaran mikroba pada bahan pangan merupakan hasil kontaminasi langsung atau tidak langsung dengan sumber-sumber penemar mikroba, seperti air, debu, udara, tanah dan alat-alat pengolah baik yang terjadi selama proses produksi atau penyiapan untuk meminimalkan jumlah bakteri, sebaiknya cara pengangutan yang benar seharusnya menggunakan kendaraan berpendingin atau cooler box agar bakteri tidak berkembang (BPOM RI,2008).

Keberadaan Escherichia Coli dalam air atau makanan juga dianggap memiliki korelasi tinggi dengan ditemukannya patogen pada pangan. pangan tercemar oleh patogen memiliki peran sebagai timbulnya penyakit salah satunya adalah diare (Wahyu dan Dwi Atmiati, 2012).

\section{KESIMPULAN}

Teknik Penyembelihan ayam di Tempat Pemotongan Ayam (TPA) Kecamatan Menes telah sesuai dengan persyaratan yang di keluarkan LPPOM MUI (2011). Proses pengeluaran darah pada teknik pemotongan ayam dikeluarkan secara sempurna yang merupakan hasil Uji Malachite Green, semua sampel pengeluaran darahnya sempurnya atau Negatif bangkai.

Angka cemaran Escherichia Coli dari uji mikrobiologi yang dilakukan terhadap karkas ayam untuk TPA Kecamatan menes, melebihi batas maksimum cemaranEscherichia Coli yaitu $2,6 \times 10^{4}$ melebihi batas maksimum $1 \times 10^{1}$.

\section{DAFTAR PUSTAKA}

Al Rasyid, H. (2014). Dasar-dasar Statistik Terapan. Bandung: Program Pascasarjana, Unpad.

Anonim (1996b). Petunjuk Praktikum Daging. Kursus Singkat Jaminan Mutu Dalam Industri Daging di IPB, Bogor.

[BPOM RI] Badan Pengawas Obat Dan Makanan Republik Indonesia. 2008. Pengujian Mikrobiologi Pangan. 9(2): 1-11.

Delfita rina. 2013. Evaluasi Teknik Pemotongan Ayam Ditinjau dari Kehalalan dan Keamanan Pangan Di Kabupaten Tanah Datar, Batusangkar.

LPPOM MUI, Lembaga Pengkajian Pangan Obat-obatan dan Kosmetika Majlis Ulama Indonesia. 2011.Pedoman Pengelolaan Rumah Potong Unggas (RPU) Halal. Lembaga Pengkajian Pangan Obat-obatan dan Kosmetika Majlis Ulama Indonesia

Marwan bin Musa, 2012. Ensiklopedia Islam: Fikih Penyembelihan Hewan, http://wawasankeislaman.bogspot.com/2012/02/fiqhmenyembelihhewan.html18jun2012

SNI. 2009. Batas Maksimum Cemaran Mikroba dalam Pangan. SNI 7388:2009

SNI.2009. Mutu Karkas dan Daging Ayam. SNI 3924:2009

Wahyu dan Dwi. 2012. Faktor-faktor Yang Berhubungan Dengan Keberadaan Bakteri Escherichia Coli Pada Jajanan Es buah Yang Dijual Di Sekitar Pusat Kota Temanggung. Semarang. 